Jurnal Layanan Masyarakat (Journal of Public Service), vol 4 no 1 Tahun 2020, halaman 208-218

\title{
INTEGRATED PROGRAMS (IP) PADA ROGRAM KEMITRAAN MASYARAKAT (PKM) DI UKM BUNDA SUKOLILO BARU, KECAMATAN BULAK, SURABAYA
}

\author{
(INTEGRATED PROGRAMS (IP) IN THE COMMUNITY PARTNERSHIP \\ PROGRAM (PKM) IN UKM BUNDA SUKOLILO BARU BULAK, SURABAYA)
}

\author{
Theresia Widihartanti ${ }^{1}$, Aniek Sulestiani ${ }^{2}$, Titiek Indhira Agustin ${ }^{3}$, Nirmalasari Idha \\ Wijaya $^{4}$, Urip Prayogi ${ }^{5}$ \\ ${ }_{1,2,3,4,5}$ FTKIP Universitas Hang Tuah Surabaya \\ Email: titiekagustin@gmail.com
}

\begin{abstract}
Sukolilo Baru is one of the tourist destination centers focused on selling dried and semi-finished fish products so that it is much sought after by tourists. However, the arrangement of processing rooms is far from adequate standards. Integrated Programs (IP) in the community service include (a) Tutorial on the cultivation of eggplant and sea cucumbers; (b) Tutorial on GMP; (c) Making crackers drying tools as appropriate technology. Drying crackers made from seafood still relies on sunlight and still uses space on the edges of the road. One of the tools needed is a weatherproof, eggplant and sea cucumber drying tool. This has become the foundation of the Faculty of Engineering and Marine Sciences of UHT to implement knowledge in its engineering field to make an effective drying tool by utilizing the limited land, which is above the storeroom of dried eggplant and sea cucumbers. By using the glass drying device, the drying time will be 3 days from 7-10 days, so that the effectiveness of the drying tool has been proven; (d) Arrangement of PIRT as the legality of the product for consumption. Thus, the Integrated Programs (IP) implemented by the FTIK community service team succeeded in improving the welfare of Sukolilo Baru, Surabaya.
\end{abstract}

Keywords: appropriate technology, Integrated Programs (IP), knowledge implementation

\begin{abstract}
abstrak
Kelurahan Sukolilo Baru merupakan salah satu pusat tujuan wisata fokus pada penjualan produk ikan kering dan setengah jadi sehingga banyak diminati oleh wisatawan. Namun, penataan ruang pengolahan jauh dari standar memadai. Integrated Programs (IP) pada pengabdian kepada masyarakat tersebut meliputi (a) Tutorial tentang budidaya terung dan teripang; (b) Tutorial tentang GMP; (c) Pembuatan alat penjemur kerupuk sebagai teknologi tepat guna. Penjemuran bahan kerupuk berbahan baku hasil laut masih mengandalkan sinar matahari dan masih memakai ruang di pinggir-pinggir jalan. Salah satu alat yang dibutuhkan adalah alat penjemuran terung dan teripang basah yang tahan cuaca. Hal inilah yang menjadi landasan Fakultas Teknik dan Ilmu Kelautan UHT untuk mengimplementasikan pengetahuan dalam bidang tekniknya untuk membuat alat penjemur yang tepat guna dengan memanfaatkan lahan yang terbatas, yaitu di atas gudang penyimpanan terung dan teripang kering. Dengan menggunakan alat penjemur kaca tersebut, lama penjemuran menjadi 3 hari dari sebelumnya 7-10 hari, sehingga efektifitas alat penjemur tersebut telah terbukti; (d) Pengurusan PIRT sebagai legalitas produk untuk dikonsumsi. Dengan demikian, Integrated Programs (IP) yang dilaksanakan oleh tim Penmas FTIK berhasil dalam meningkatkan kesejahteraan warga Kelurahan Sukolilo Baru, Surabaya.
\end{abstract}

Kata kunci: implementasi pengetahuan, Integrated Programs (IP), teknologi tepat guna 


\section{PENDAHULUAN}

KM Bunda merupakan perkumpulan para bapak dan ibu warga Kelurahan Sukolilo Baru, Surabaya yang mempunyai usaha toko penjual kerupuk berbahan hasil laut misalnya terung, teripang ikan, dan kupang yang berlokasi sepanjang pinggir jalan di Kelurahan Sukolilo Baru dekat pantai wisata Kenjeran. Mereka berkisar berumur 25 - 45 tahun. Mata pencaharian para bapak adalah mencari ikan dan para ibu akan menjual produk hasil laut yang dapat berupa kerupuk, ikan asin dan ikan asap, serta produk olahan lainnya. Segmentasi pasar yang meliputi daya beli, lokasi, sikap, dan kebiasaan pembeli (Sudaryono, 2017: 271) UKM Bunda yang adalah wisatawan- wisatawan lokal dan warga kota Surabaya yang menikmati pantai wisata KENPARK, Kenjeran menentukan turun tingginya penghasilan para penjual produk olahan kerupuk di wilayah tersebut. Kelurahan Sukolilo Baru merupakan kawasan pesisir yaitu pantai Kenjeran yang memiliki potensi wisata, tetapi juga potensi ekonomi dan ekologis sehingga produk olahan dari hasil laut dapat layak dikonsumsi oleh masyarakat banyak.

Aspek sosial dari para warga Kelurahan Sukolilo Baru, Surabaya anggota UKM Bunda adalah mereka masih memerlukan informasi yang sangat tepat dalam beberapa masalah sosial yang timbul akhir-akhir ini berupa keterbatasan nara sumber yang dapat memberikan informasi yang akurat mengenai cara yang tepat mengelola bahan kerupuk hasil laut, prosedur hukum legalitas produk untuk dikonsumsi, cara penjemuran yang tepat dengan alat yang tepat guna, dan cara pengemasan produk yang tepat serta pemasaran produk yang up-to-date. Kecenderungan selera tertentu dari konsumen, kurangnya persediaan produk pesaing, dan meningkatnya daya beli masyarakat (Sudaryono, 2017: 268) di sekitar UKM Bunda dapat meningkatkan tahap produksi UKM Bunda dari Tahap Permulaan menjadi Tahap Pertumbuhan (IBI, 2017: 157). Hal-hal tersebut dirumuskan secara detil dalam rapat persiapan PKM 2017 oleh semua anggota pengabdian kepada masyarakat tim FTIK sebagai tim pelaksana.

Aspek lain dari kegiatan ini adalah adanya kesepakatan bersama yaitu dengan adanya MOU bahwa Kelurahan Sukolilo Baru, Surabaya merupakan desa mitra/binaan Univeristas Hang Tuah sejak 2016 sehingga tim pelaksana memaksimalkan ilmu dan pengetahuan mereka dalam meningkatkan kesejahteraan desa mitra / binaan.

Kegiatan pengabdian kepada masyarakat 2017 Universitas Hang Tuah Surabaya ini bertujuan untuk menerapkan keilmuan PT kepada masyarakat sekitar terutama kepada desa Binaan/Mitra sehingga masyarakat dapat merasakan manfaat dalam mencapai kemakmuran yang berasal dari kepakaran dosen dan mahasiswa Universitas Hang Tuah, Surabaya. Karena UKM Bunda merupakan kelompok usaha kecil menengah yang secara organisasi belum mempunyai data pendirian yang secara hukum belum mempunyai legalitas, maka data pendirian UKM ini belum terdata.

Semenjak MOU antara Universitas Hang Tuah dan UKM Bunda sebagai desa binaan ditanda- tangani, kegiatan pengabdian kepada masyarakat yang dilaksanakan adalah kegiatan amal kesehatan kemasyarakat, kesehatan gigi dan mulut, penanganan masalah 
narkoba, managemen asset desa, keselamatan kerja dan pemasaran produk secara online untuk meng-update informasi dalam penjualan produk olahan kering. Sebelumnya, tim FTIK juga telah memberikan penyuluhan tentang Good Manufactured Products (GMP) dan pendampingan dalam pembuatan PIRT, SIUP dan TDP.

Dengan adanya produksi kerupuk berbahan terung dan teripang, pemasok kerupuk setengah-jadi UD Barokah yaitu Ibu Hj.Lilik merupakan target tim Penmas FTIK. Beberapa pemilik toko penjual kerupuk terung dan teripang serta bapak-bapak nelayan pencari terung dan teripang diberikan pengetahuan dan informasi tentang ekosistem terung dan teripang sehingga banyak dari mereka yang bertanya banyak tentang terbatasnya terung dan teripang di wilayah tersebut, waktu yang tepat untuk mencari terung dan teripang, sampai cara memanennya.

Alat penjemur yang tepat guna juga merupakan masalah yang sangat urgen. Sampai saat ini, ibu-ibu UKM Bunda hanya mengandalkan cuaca yang terang dan para-para bambu yang ditaruh di atas rumah untuk menjemur, yang sebelumnya mereka memakai pelataran rumah di pinggir jalan yang kemudian tempat tersebut DILARANG untuk lahan penjemuran.

Masalah produksi yang harus layak konsumsi sesuai standar DINKES dengan adanya kepemilikan PIRT dan SIUP juga merupakan masalah yang belum teratasi di UKM Bunda. Dari sekitar 40 anggota UKM, hanya sekitar 8 orang pemilik usaha yang memiliki PIRT. Sesuai dengan peraturan baru DINKES, hanya pemilik PIRT saja, atau setidaknya SIUP, yang bisa mengikuti kegiatan-kegiatan pameran produk olahan yang diadakan oleh pemerintah daerah. Hal tersebut mempersempit kesempatan bagi anggota UKM Bunda untuk mengikuti kegiatan pameran produk olahan tersebut.

Berhubungan dengan adanya kepemilikan PIRT, adanya beberapa peraturan dalam pengemasan produk juga masih menjadi kendala di UKM Bunda. Banyak pemilik toko masih memakai pengemasan tradisional yaitu memakai plastik grosiran besar dan platik tanpa label sebagai pembungkus kerupuk. Plastik tersebut hanya akan ditutup dengan sealer biasa yang masih sering kelekatan sealernya masih sangat minim. Hal inilah yang menurunkan minat pembeli karena ketika beberapa hari saja, kualitas kerupuk menjadi berkurang.

\section{METODE PENGABDIAN MASYARAKAT}

Metode pengabdian masyarakat yang dilakukan adalah dengan melakukan pemberian teknologi tepat guna (TTG) dan pendampingan terhadap masyarakat dengan dilakukan melalui beberapa tahapan. Tahap persiapan dengan melakukan survei. Survei dilakukan 1 bulan sebelum pelaksanaan pengabdian kepada masyarakat untuk mengetahui kondisi riil dan permasalahan yang ada di UKM Bunda, Kelurahan Sukolilo Baru, Surabaya. Pertemuan kedua pihak yaitu perwakilan tiap jurusan dan Lurah Kelurahan Sukolilo Baru dan perwakian desa diadakan di kantor kelurahan Sukolilo Baru. Tim pelaksana membuat ringkasan permasalahan yang dapat dikerjakan oleh setiap tim jurusan yang terlibat. Metode Integrated Programs (IP) ini dilakukan karena setiap kegiatan berkesinambungan dengan 
materi produk olahan yang sama, alat yang tepat-guna bagi produksi, legalitas usaha produk, dan kebutuhan lainnya yang sesuai dengan hasil kegiatan sebelumnya.

Pada tahap pelaksanaan, IP dilihat dari materi penyuluhan yang diberikan, kegunaan alat penjemur untuk bahan terung/teripang, kebutuhan ke-legalan produk dengan kepemilikan PIRT, dan pendampingan pengemasan yang sesuai dengan standar konsumsi pelanggan. Kontinuitas dan keterkaitan kegiatan- kegiatan inilah yang disebut Integrated Programs (IP) yang dijabarkan dalam perumusan kegiatan sebagai berikut: 1) Tim Jurusan Oseanografi memberikan penyuluhan tentang ekosistem terung dan teripang yang melibatkan para nelayan pencari terung dan teripang; 2)Tim Jurusan Teknik mengamati kebutuhan alat penjemur yang memakai lokasi atap gudang terung / teripang rumah Ibu Hj.Lilik dan kesesuaian ukuran alat penjemur kaca tersebut. Tim Jurusan Teknik juga akan memberikan pendampingan pengemasan dan pemasaran online yang didampingi tim Jurusan Perikanan dalam hal pengemasan produknya; 3)Tim Jurusan Perikanan memberikan pendampingan pengurusan PIRT dan SIUP serta pengolahan produk secara higienis.

Dari perencanaan tersebut, Tim Pelaksana PKM FTIK secara kontinu melaksanakan kegiatan-kegiatan dengan pembuatan tabel jadwal kegiatan penmas dari perencanaan pada bulan Maret sampai pada pelaksanaan dan penutupan pada bulan Mei.

\section{HASIL DAN PEMBAHASAN}

\section{Penyuluhan Ekosistem Terung dan Teripang}

Penyuluhan tentang ekosistem terung dan teripang diberikan oleh Dr. Nirmalasari Idha W., SPi., M.Si. berjudul 'Ekologi Teripang' sehingga nelayan di daerah Sukolilo Baru dapat membudidayakannya secara berkesinambungan karena daerah tersebut masih mengambil bahan baku dari daerah Gresik, Lamongan dan Madura. Penyuluhan tersebut membahas habitat dan jenis teripang, biologi teripang, permasalahan teripang, perdagangan teripang, dan konservasi dan pengelolaan teripang. Diharapkan, penyuluhan tersebut meningkatkan pengetahuan yang lebih mendalam tentang teripang sehingga hasilnya lebih memuaskan. Setelah penyuluhan, para nelayan mengajukan beberapa pertanyaan kepada Dr. Nirmalasari Idha W, SPi., MSi. mengenai lokasi budidaya yang tepat untuk komunitas teripang tersebut.

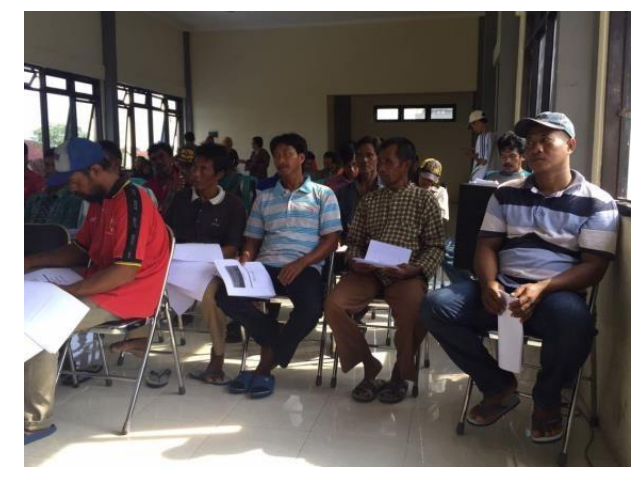

Gambar 1. Peserta Penyuluhan tentang Ekologi Teripang 


\section{Pembuatan Alat Produksi}

Alat pengering bahan terung dan teripang yang dibuat oleh tim FTIK menggunakan/memanfaatkan panas matahari karena terbuat dari kaca yang dapat memaksimalkan panas matahari. Pada saat ini pada proses pengeringan masih membutuhkan waktu 7-10 hari penjemuran secara alami di atap-atap rumah karena lahan untuk penjemuran yang sebelumnya adalah pinggir jalan. Lahan tersebut tersebut saat ini dibuat untuk penataan ruang yang lebih lapang dan untuk transportasi umum. Penggunaan alat pengering kaca menurunkan lama pengeringan dari 7 hari menjadi 3 hari. Dengan lokasi yang memakai lahan atas atap rumah belakang, alat pengering tersebut melindungi bahan terung dan teripang dari air hujan dan melipatgandakan panas matahari. Desain gambar alat pengering tersebut seperti di bawah berikut ini:
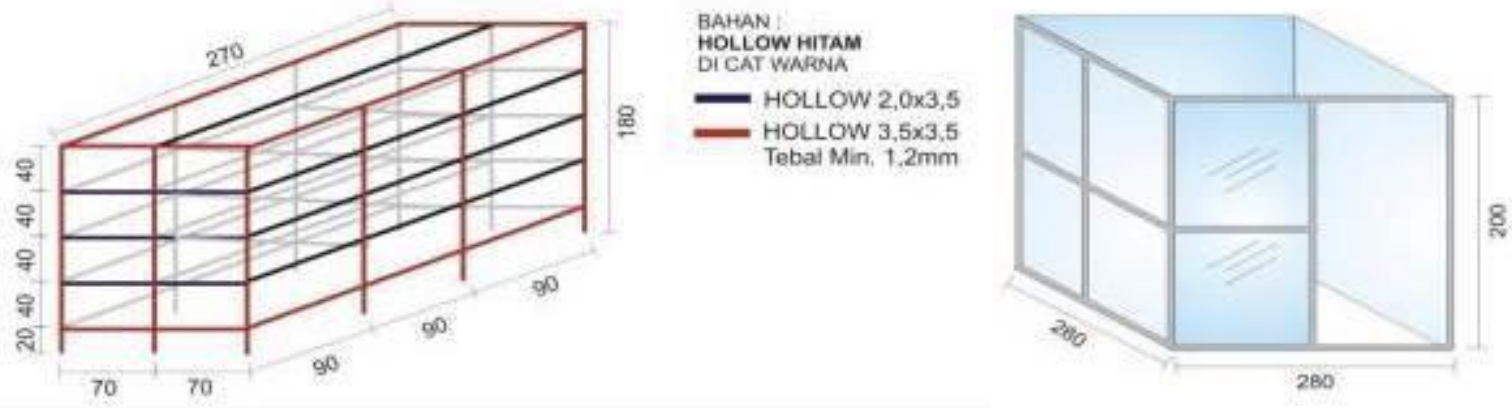

\section{Gambar 2. Desain Pengering Rumah Kaca}

Petunjuk pemakaian: Alat pengering diletakkan di atas atap rumah bagian belakang. Parapara bambu yang telah diisi dengan terung dan teripang dimasukkan ke dalam alat pengering. Para-para bambu diletakkan di atas rak/separator yang terbuat dari besi di dalam alat pengering. Agar panas matahari dapat memaksimalkan pengeringan dan menghindarkan air hujan masuk ke dalam alat pengering, pintu kaca ditutup dan pengecekan hasil pengeringan bisa dilaksanakan tiap hari atau per 2 hari. Ambil para-para bambu dan terung/teripang yang sudah kering untuk diganti dengan yang masih basah.Terung dan teripang siap untuk diolah/digoreng memakai minyak goreng atau pasir yang khusus untuk menggoreng terung / teripang. 


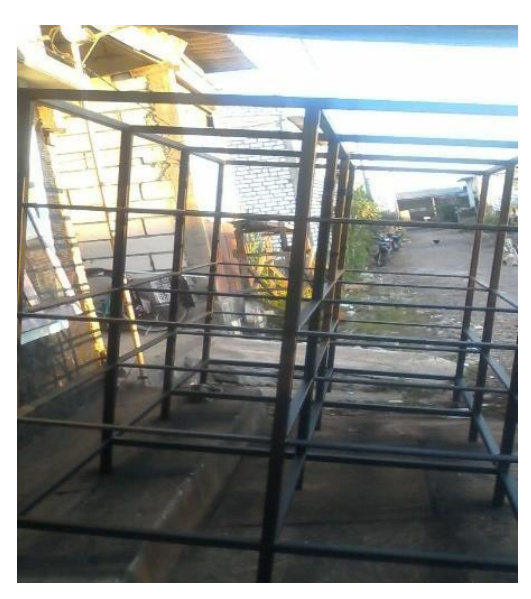

Gambar 3 . Kerangka besi sebagai Rak di dalam Alat Pengering Terung/Teripang

Untuk perbaikan alat pembersih terung dan teripang, tim FTIK memperbaiki kondisi alat dengan beberapa perbaikan dalam sistim memasukkan terung dan teripang yang penuh dengan lumpur. Ada 2 perbaikan utama pada alat pembersih terung dan teripang yang telah dilaksanakan pada bulan Juli 2017 yaitu: Penambalan kembali badan alat pembersih (sejenis molen semen) yang kondisinya banyak terdapat lubang-lubang sehingga sistim pengeluaran kotoran menjadi terhambat. Penambahan saringan/penutup dengan lubang-lubang kecil pada lubang besar/pintu yang digunakan untuk memasukkan terung dan teripang karena sebelumnya tidak terdapat saringan tersebut sehingga pada waktu proses pemutaran alat molen, banyak terung dan teripang yang keluar dari alat molen tersebut. Diharapkan, penutup bersaring tesebut dapat mencegah terung dan teripang terlempar keluar alat molen.

Berikut ini beberapa gambar pembenahan alat pembersih/molen yang telah dilaksanakan oleh tim FTIK:

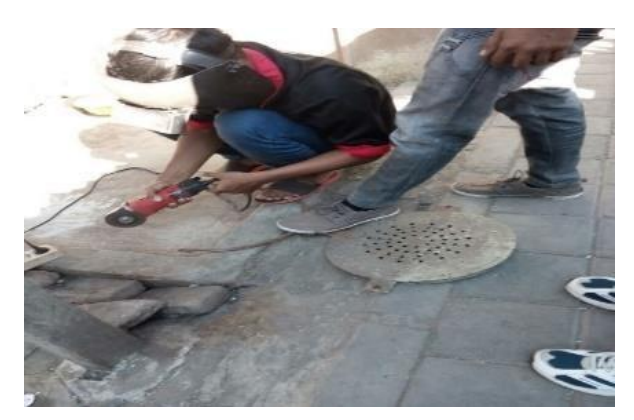

Gambar 4 Penambahan Alat Penyaring pada Penutup Mole 


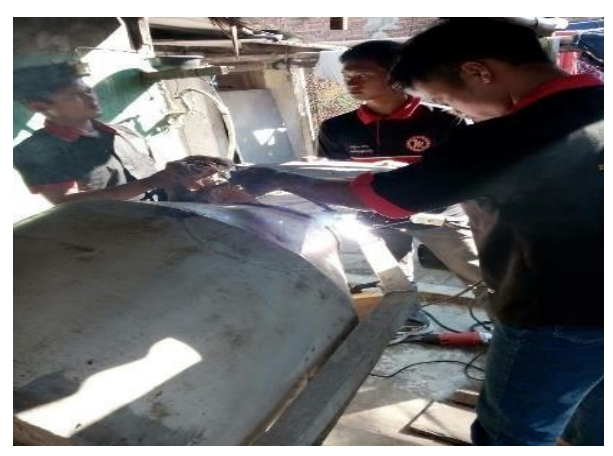

Gambar 4. Pemasangan Penyaring pada Penutup Alat Molen

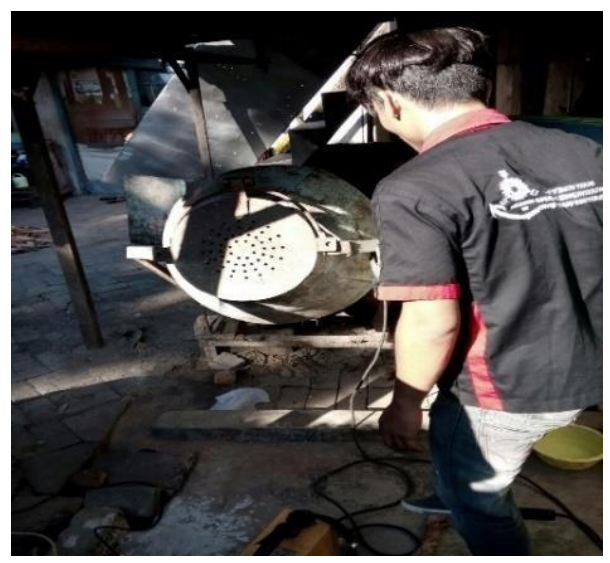

Gambar 5. Uji coba Alat Molen setelah Pemasangan Penyaring

\section{Pendampingan PIRT dan Pengolahan}

Kegiatan ini dipandu oleh Ibu Titiek Indhira A., S.Pi., MP. dan bertujuan untuk mendampingi UD Barokah yang dimiliki oleh Ibu Hj. Lilik Hartatik yang membutuhkan penerbitan SIUP dan PIRT sesuai standar yang telah ditetapkan. Dengan adanya PIRT maka semua produk yang dihasilkan oleh UD Barokah akan menjadi legal secara hukum. Pendampingan telah dilaksanakan dari pemenuhan persyaratan penerbitan SIUP dan PIRT, keikutsertaan dalam penyuluhan Dinkes tentang produk yang legal dan higienis, kepemilikan SIUP dan PIRT, penerbitan label untuk tiap variasi rasa yang diproduksi, dan pen-display-an produk sehingga menjadi produk-siap-saji sehingga UD Barokah tersebut dapat meningkatkan tingkat legalitas pemasaran dan konsumsinya yang sebelumnya hanyalah produk-setengah jadi, dan pada akhirnya produk tersebut siap dipasarkan secara on-line.

\section{Pendampingan Pembuatan Kemasan}

Kegiatan pendampingan pembuatan kemasan bertujuan untuk memberikan pelatihan kepada anggota UD Barokah dalam hal desain dan pembuatan kemasan produk. Dalam hal ini 
desain akan sesuaikan dengan standar yang telah ditetapkan dimulai dengan cara penggunaan handsealer, pembuatan logo produk, cara mengemas yang efektif dan maintenance kemasan tersebut. Desain yang menarik dan sesuai standar akan menjadikan produk tahan lama dan mempunyai nilai jual yang lebih. Dalam hal ini, terdapat dua jenis tipe produk dengan dua rasa produk yang disetujui dalam pengurusan SIUP dan PIRT oleh Ibu Hj.Lilik Hartatik.

Beberapa hal mengenai pengemasan produk hasil perikanan adalah: Pengemasan yang dipakai yaitu model plastic yang mempunyai klip perekat agar udara tidak merusak produksiap-makan tersebut. Ukuran plastic kemasan yaitu tinggi $17,5 \mathrm{~cm}$ X lebar $14 \mathrm{~cm}$ Berat teripang dalam plastic kemasan yaitu 150 gram.

Langkah-langkah pengemasan: 1) Tempelkan stiker kemasan; 2) Buka klip atau perekat pada bagian atas plastic; 3) Takar atau timbang teripang/terung yang akan dikemas seberat 150 gr; 4) Masukkan teripang/terung yang sudah ditakar; 5) Rekatkan klip atau perekat pada bagian atas plastik; 6) Proses pengemasan selesai dilakukan.

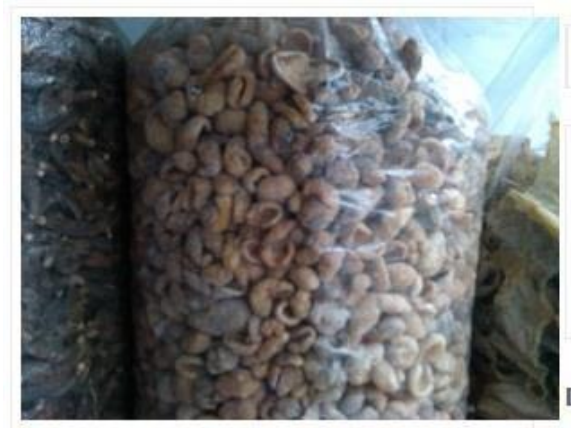

Gambar 6. Terung dalam bentuk grosiran

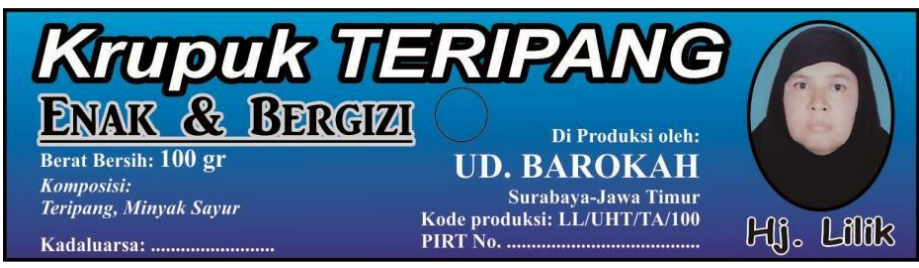

Gambar 7. Logo Produksi berbahan Teripang (Bagian Depan) 


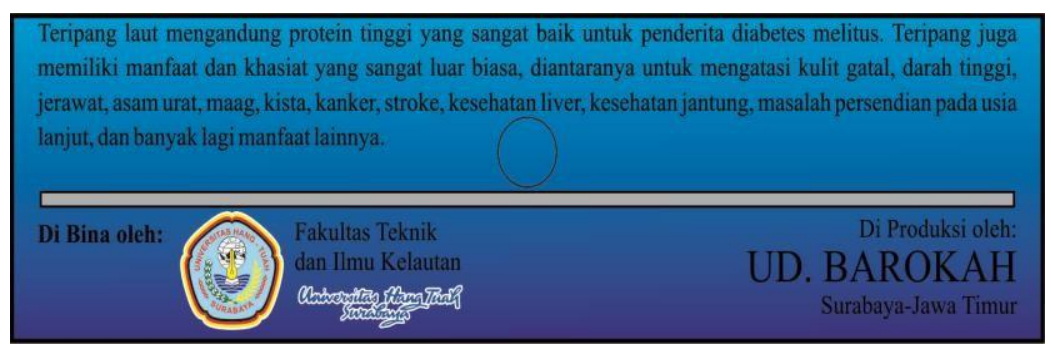

Gambar 8. Logo Produksi berbahan Teripang (Bagian Belakang)

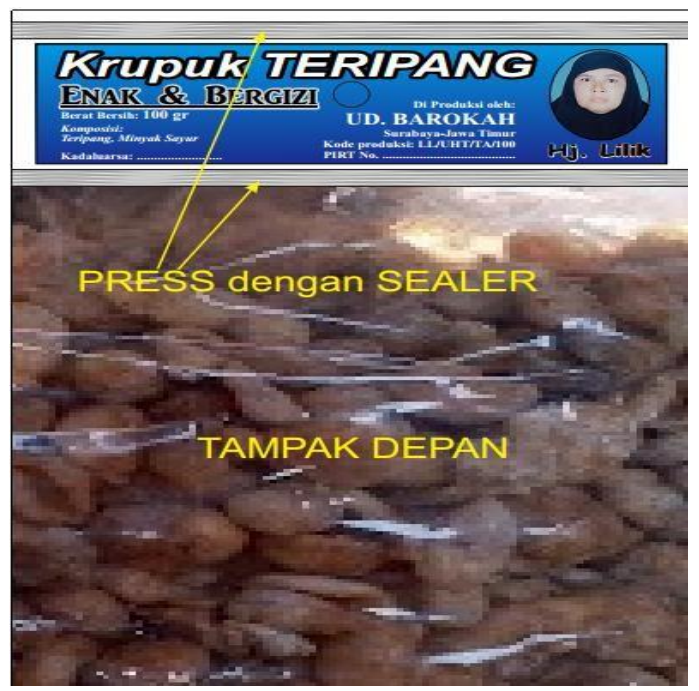

Gambar 9. Produk Teripang yang telah dikemas (tampak depan)

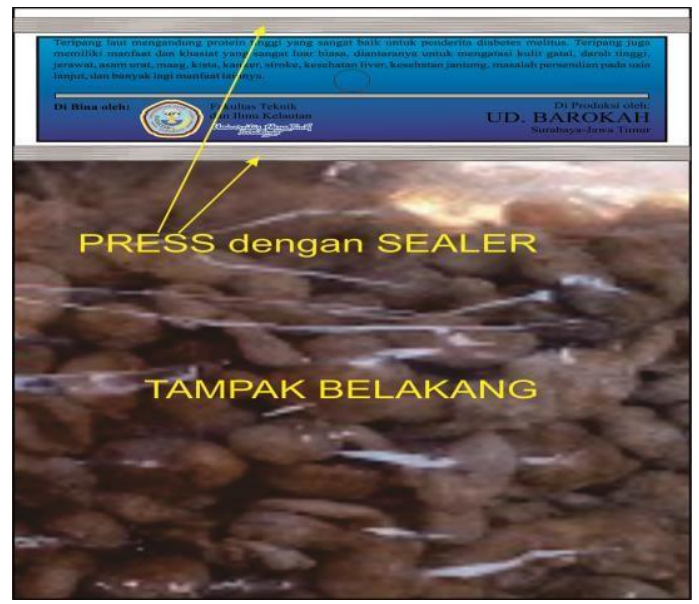

Gambar 10. Produk Teripang yang telah dikemas (tampak belakang)

Beberapa hal yang diterapkan pada produk UD. Barokah tersebut adalah: Berat teripang 
yang dipakai dalam kemasan adalah 100gram. Teknik pengemasan yang menarik minat pembeli yaitu pengemasan usahakan krupuk teripang/terung ditata serapi mungkin.

\section{Pendampingan dan Pelatihan Pemasaran}

Pemasaran produk UD Barokah dilaksanakan setelah proses produksi dan pengemasan terpenuhi. Pelatihan tentang pemasaran produk secara manual maupun on-line dilaksanakan setelah SIUP, PIRT dan pengesahan label produk terung dan teripang telah dilakukan oleh pihak-pihak yang terkait. Pengurangan rantai distributor dapat menekan cost, sehingga harga produk UD Barokah dapat bersaing dan produk dapat secara cepat dikonsumsi oleh pembeli. Pemberian variasi rasa pada produk terung dan teripang sebagai produk-siap-saji dapat meningkatkan jumlah konsumen dan penggunaan gadget dapat membuat anggota UD Barokah dapat 'melek teknologi' yang mengarah pada penjualan luar kota.

Penyuluhan Pemasaran meliputi

Pengenalan tentang Pemasaran: 1) Pemasaran dilakukan setelah PIRT dari Dinkes didapatkan; 2) Pemasaran dilakukan setelah kemasan selesai dilakukan; 3) Pemasaran difokuskan pada pemasaran online; 4)Pemasaran online untuk awal dilakukan di facebook, whatsapp dan website tidak berbayar yang dibuat sekali (blogspot.com atau wordpress.com.) Sementara Teknis Pemasaran online dilakukan dengan cara sharing fotofoto produk secara langsung dan sharing poster (gambaran produk detail disertai manfaatnya).

Langkah-langkah pemasaran adalah sebagai berikut:1) PIRT dari Dinkes didapatkan dan pengemasan selesai dilakukan; 2) Pemberian brand (Nama, tempat pembuatan, dan keunggulannya); 3) Pengambilan gambar produk, pembuatan poster dan alat publikasi; 4) Pembuatan media sosial online (facebook, twitter, line, id); 5) Pemasangan publikasi tool pada media social (facebook, twitter, WhatsApp group, line group); 6) Pelanggan memesan produk dan produsen mengirim produk pesanan; 7) Tidak ada agen yang dibutuhkan karena customer langsung menghubungi pihak produsen dan produsen mengirim melalui pos.

Pengawasan pemasan online dilakukan rutin oleh admin dengan cara update rutin produk di media sosial dan fast-response menanggapi calon konsumen atau konsumen.

\section{PENUTUP}

\section{Simpulan}

Fakultas Teknik dan Ilmu Kelautan UHT memiliki tanggungjawab untuk mengimplementasikan pengetahuan dalam bidang tekniknya. Kegiatan yang dilakukan dalam bentuk Integrated Programs (IP) pada pengabdian kepada masyarakat tersebut meliputi (a) Tutorial tentang budidaya terung dan teripang; (b) Tutorial tentang GMP; (c) Pembuatan alat penjemur kerupuk sebagai teknologi tepat gunau ntuk membuat alat penjemur yang tepat guna dengan memanfaatkan lahan yang terbatas, yaitu di atas gudang penyimpanan terung dan teripang kering. Dengan menggunakan alat penjemur kaca tersebut, lama penjemuran menjadi 3 hari dari sebelumnya 7-10 hari, sehingga efektifitas alat penjemur tersebut telah terbukti; (d)Pengurusan PIRT sebagai legalitas produk untuk dikonsumsi. Dengan demikian, Integrated Programs (IP) yang dilaksanakan oleh tim Penmas FTIK berhasil dalam meningkatkan kesejahteraan warga Kelurahan Sukolilo Baru, Surabaya. 


\section{DAFTAR PUSTAKA}

Ikatan Bankir Indonesia. 2017. Wealth Management: Produk dan Analisis. Jakarta: PT Gramedia Pustaka.

Sudaryono. 2017. Pengantar Manajemen: Teori dan Kasus. Yogyakarta : Centre for Academic Publishing Service (CAPS) 